\title{
Production of Thermostable $\alpha$-Amylase Through Solid State Fermentation (SSF) by Using Thermophilic Anoxybacillus sp.
}

\author{
Termofilik Anoxybacillus sp. Kullanarak Katı Faz Fermantasyonu \\ (SSF) ile Isılkararlı $\alpha$-Amilaz Üretimi
}

\author{
Research Article
}

\section{Serkan Yalçın ${ }^{*}$ and Sadin Özdemir²}

'Dep. of Chemical and Chemical Processing Technologies, Technical Science Vocational School, Mersin University, Mersin, Turkey. ${ }^{2}$ Food Processing Programme, Technical Science Vocational School, Mersin University, Yenisehir, Mersin, Turkey.

\section{A B S TR AC T}

Tr

he production of extracellular $\alpha$-amylase (1,4- $\alpha$-D-glucan glucanohydrolase, EC 3.2.1.1) by a newly isolated thermophilic bacterium Anoxybacillus sp. was studied in solid state fermentation (SSF). Bacterial strain was isolated from a thermal spring of Ömer, Afyonkarahisar in Turkey. Agricultural wastes such as banana husk, wheat bran, rice husk, apple bark, orange bark, maize oil cake, lentil bran and pistachio shell were used for $\alpha$-amylase production as solid substrates. Growth on rice husk gave the highest $\alpha$-amylase activity. The maximum enzyme activity obtained was $3.628 \mathrm{U} / \mathrm{mg}$ of under optimum conditions of an fermentation time of $48 \mathrm{~h}$, an incubation temperature of $60^{\circ} \mathrm{C}$, a pH of 6.0 , a substrat particle size $1.500 \mu \mathrm{m}$, an initial moisture level of $60 \%$ and an inoculum level of $40 \%(\mathrm{v} / \mathrm{w})$.

\section{Key Words}

Agricultural waste, $\alpha$-amylase, solid-state fermentation (SSF), thermophilic bacterium.

\section{öz}

\begin{abstract}
- kstrasellüler $\alpha$-amilaz (1,4- $\alpha$-D-glukan glukanohidrolaz, EC 3.2.1.1) üretimi yeni izole edilmiş bir termofilik — bakteri olan Anoxybacillus sp. kullanılarak katı faz fermantasyon (SSF) yöntemiyle gerçekleştirilmiştir. Bakteri ırkı, Türkiye'de Afyonkarahisar, Ömer, termal kaplıcasından izole edilmiştir. $\alpha$-Amilaz üretimi için, muz kabuğu, buğday kepeği, pirinç kabuğu, elma kabuğu, portakal kabuğu, mısır yağı pastası, mercimek kepeği ve antep fıstığı kabuğu gibi tarımsal atıklar katı substrat olarak kullanılmıştır. En yüksek $\alpha$-amilaz aktivitesi, pirinç kabuğu üzerindeki mikroorganizma üremesinde elde edilmiştir. Maksimum enzim aktivitesi, 3.628 U/mg, 48 saatlik fermantasyon süresi, $60^{\circ} \mathrm{C}$ 'lik bir inkübasyon sıcaklığı, pH 6.0, substrat parçacık boyutu $1.500 \mu \mathrm{m}$, başlangıç nem seviyesi \%60 ve aşılama seviyesi \%40 (v/w) optimum koşulları altında elde edilmiştir
\end{abstract}

\section{Anahtar Kelimeler}

Tarımsal atık, $\alpha$-amilaz, katı hal fermantasyon (SSF), termofilik bakteri.

Article History: Received: Sep 08, 2017; Revised: Oct 26, 2017; Accepted: Jun 26, 2018; Available Online: Feb $20,2018$.

DOI: 10.15671/HJBC.2018.217

Correspondence to: M.S. Yalçın; Dep. Chem. Chemic. Process. Technol., Techn. Sci. Voc. Sch., Mersin University, Mersin, Turkey. 


\section{INTRODUCTION}

-Amylase (1,4- $\alpha$-D-glucan glucanohydrolase, $\alpha_{\text {EC 3.2.1.1) is a common secretory enzyme that }}$ catalyze the hydrolysis of internal $\alpha$-D- $(1,4)$ glycosidic bonds of starch at random points [1]. $\alpha$-amylase is an important enzyme for industrial operations such as starch processing, pulp industries, textile, yeasting, baking, distillation industries and pharmaceutics [2,3]. This enzyme represents an industrial enzyme category which has a $25 \%$ share (approximately) in the enzyme sector $[4,5]$. $\alpha$-amylase can be produced from various sources such as plants, animals and microorganisms. Enzymes originating from microbial sources generally meet industrial demand [4].

Solid state fermentation (SSF) is a process where microorganisms grow without any free water or in an environment containing a very small amount of free water. Due to its historical importance, it is being used for the production of basic foodstuff such as bread and cheese in the West and koji in the East for thousands of years [6]. Considering the last century and the past couple of decades, it is still being used for the production of biomolecules and products that are important for many industries, including food, pharmaceuticals, textile, biochemicals, bioenergy, and others $[7,8]$. As compared to conventional submerged fermentation (SmF), SSF offers important advantages such as low energy requirements, high productivity and less inhibitor effect for enzymatic production [9]. Its application at industrial scale, however, seems to be limited because of technological issues such as reactor design, heat transfer problems or cost of sterilization [10].

Thermophilic bacteria usually grow at temperatures as high as $50-80^{\circ} \mathrm{C}$ [11]. Because thermophilic character is not associated with Gram identity (Gram + or -), spore formation state (spore forming or not) and respiratory type (aerobic or anaerobic) of the bacteria, thermophilic members can be found in each bacteria group. Thermophilic bacteria can produce DNA polymerases, lipases, amylases, proteases, xylanases and also exo-polysaccharides resistant to high temperature, salt and extreme $\mathrm{pH}$ conditions [12]. For these reasons, thermophilic bacteria have been great attention in biotechnology in recent years by many researchers.
The aim of this investigation was the optimization of $\alpha$-amylase production by using thermophilic bacterium Anoxybacillus sp. under SSF. For this reason, the various process parameters were checked out such as various agriculture wastes, fermentation time, temperature and $\mathrm{pH}$, particle size, initial moisture level, inoculum volume and influence of different metal ions.

\section{MATERIALS and METHODS}

\section{Isolation and Identification of Thermophilic Bacterial Strain}

In this study, bacterial strain was isolated from a thermal spring of Ömer, Afyonkarahisar in Turkey. Based on the quantities of $\alpha$-amylase secreted by solid state media and the features of the enzyme, one strain was selected for following studies and identified as Anoxybacillus sp. on the basis of different biochemical and morphological tests and 16S rRNA gene sequence analysis. The phylogenetic tree was arranged with the neighbor joining process utilizing the Molecular Evolutionary Genetics Analysis (MEGA) [13].

\section{Preparation of Inoculum}

The thermophilic isolate was cultured in $50 \mathrm{~mL}$ of Nutrient Broth in a $250 \mathrm{~mL}$ glass bottle and inoculated with a loopfull of cells from one night old slant and kept at $55^{\circ} \mathrm{C}$ in a shaker (120 rpm). After $12 \mathrm{~h}$ of incubation, $1000 \mu \mathrm{L}$ of this medium was utilized for inoculation. By serial dilution and plating, the quantities of viable colonies in the inoculation medium was determined to be $7.4 \times 10^{7}$ $\mathrm{CFU} / \mathrm{mL}$.

\section{Solid-State Fermentation (SSF)}

Banana husk $(\mathrm{BH})$, wheat bran $(\mathrm{WB})$, rice husk $(\mathrm{RH})$, apple bark $(A B)$, orange bark (OB), lentil bran ( $L B)$, maize oil cake (MOC) and pistachio shell (PS) were provided from a regional market in Mersin, Turkey. One half of a gram of solid substrates which passed through sieve of $1.000 \mu \mathrm{m}$ were put into $50 \mathrm{~mL}$ glass bottle. To adjust moisture contents (\% by mass per volume), Tris $\mathrm{HCl}(0.1 \mathrm{M}$ and $\mathrm{pH}$ 7.0) was added and then autoclaved at $121{ }^{\circ} \mathrm{C}$ for $15 \mathrm{~min}$. The glass bottles were waited for cooling after autoclaving and then were inoculated with 1 $\mathrm{mL}$ spore suspension. After inoculation, the SSF mediums were incubated at $55^{\circ} \mathrm{C}$ at $120 \mathrm{rpm}$. 


\section{Optimization of Process Parameters}

Investigation of the influence of different physico-chemical factors and cultural conditions was necessary for the optimization of enzyme production of Anoxybacillus sp. used in SSF. The strategy was to optimize every factor independently and we studied the optimal conditions after in each experiments. Fermentation time (24-144 h), temperature (40$75^{\circ} \mathrm{C}$ ), $\mathrm{pH}$ (citrate buffer $0.1 \mathrm{M}, \mathrm{pH} 3.0,4.0,5.0$, and 6.0, Tris- $\mathrm{HCl}$ buffer $0.1 \mathrm{M}, \mathrm{pH} 7.0,8.0$, and 9.0, carbonate/bicarbonate buffer $0.1 \mathrm{M}, \mathrm{pH} 10$ ), particle size (500-2.000 $\mu \mathrm{m})$, inoculum size (10$60 \%$ by mass per volume), initial moisture level of the SSF substrate (40-70\% by mass per volume) and different metal ions $\left(\mathrm{Co}^{2+}, \mathrm{Ca}^{2+}, \mathrm{Mn}^{2+}, \mathrm{Cu}^{2+}, \mathrm{Pb}^{2+}\right.$ $\mathrm{Cd}^{2+}$ ) were optimized.

\section{Enzyme Extraction and Assay}

The fermented SSF substrates were mixed properly with water and then shaked by shaker at $120 \mathrm{rpm}$ for $60 \mathrm{~min}$. The fermented extracts were compressed using muslin cloth. The extracts were centrifuged at $10.000 \mathrm{~g}$ for $8 \mathrm{~min}$. The upper solution used as the crude enzyme after centrifugation. $\alpha$-Amylase assay was determined by Bernfeld method [14].

\section{RESULTS and DISCUSSION}

\section{Morphological, Physiological, Biochemical Tests and 16S rRNA Gene Sequence Analysis}

It was observed that isolated bacteria (SO6) were in the form of bacilli, gram positive, creates spores, mobile and thermophilic (Table 1). It was determined that this isolate was close to Anoxybacillus sp. according to the results of morphological, physiological and biochemical tests and 16 rRNA analysis (Accession no. KJ434783). Figure 1 demonstrates the phylogenetic tree analysis. 16rRNA sequence is as follows:

GCTTTTGGATCGTTAGCGGCGGACGGGTGAG TAACACGTGGGCAACCTGCCCTGTAGACGGGG ATAACACCGAGAAATCGGT-GCTAATACCGGAT AACACGAAAGGCCGCATGGTCTTTCGTTGAAAGGCGGCGCAAGCTGTCGCTACAGGATGGGCCCGCGGC-GCATTAGCTAGTTGGTGAGGTAACGGCTCACCAAGGCGACGATGCGTAGCCGACCTGAG
AGGGTGATCGGCCACACTGGGACTGAGACACG GCCCAGACTCCTACGGGAGGCAGCAGTAGGGAATCTTCCGCAATGGACGAAAGTCTGACGGAGCAAC GCCGCGTGAGCGAAGAAGGCCTTCGGGTCGTAAA GCTCTGTTGTTAGGGAAGAACAAGTACCGCAGTCACTGGCGGTACCTTGACG-GTACCTAACGAGGAAGCCACGGCTAACTACGTGCCAGCAGCCGCGGTAATACGTAGGTGGCAAGCGTTGTCCGGAATTATTGGGCGTAAAGCGCGCGCAGGCGGTTCCTTAAGT CTGATGTGAAAGCCCACGGCTCAACCGTGGAGG GTCATTGGAAACTGGG-GGACTTGAGTGCAGAAGAGGAGAGCGGAATTCCACGTGTAGCGGTGAAATGCGTAGAGATGTGGAGGAACACCAGTGGCGAAGGCGGCTCTCTGGTCTGTAACTGACG CTGAGGCGCGAAAGCGTGGGGAGCAAACAG GATTAGATACCCTGGTAGTCCACGCCGTAAACGATGAGTGCTAAGTGTTAGAGGGTATCCACCCTTTAGTGCTGTAGCTAACGCATTAAGCACTCCGC CTGGGGAGTACGCTCGCAAGAGTGAAACTCAAAGGAATTGACGGGGGCCCGCACAAGCGGTGGAACCTTGTGGTTTAATTCGAAGCAACGCGAAGAACCTTACCAGGTCTTGACATCCCCTGACAACCCGAGAAATCGGGCGTCCCCCTTCG...

\section{Effect of Different Agriculture Wastes on $\alpha$-amylase Production}

Selection of a suitable solid substrate for fermentation process in SSF method is an important factor [15]. Various agroindustrial materials, particularly $\mathrm{BH}, \mathrm{WB}, \mathrm{RH}, \mathrm{AB}, \mathrm{OB}, \mathrm{MOC}, \mathrm{LB}$ and $\mathrm{PS}$ were tested for the selection of the most convenient substrate material to optimize bacterial growth and enzyme production. As can be seen in Figure 2, maximum amylase production (2.532 U/mg) was obtained in a medium containing $\mathrm{RH}$ alone as the substrate. The order of production of $\alpha$-amylase from maximum to minimum was found to be $\mathrm{RH}>\mathrm{WB}>\mathrm{MOC}>\mathrm{BH}>\mathrm{OB}>\mathrm{AB}>\mathrm{LB}>\mathrm{PS}$. Therefore, $\mathrm{RH}$ was used as a substrate in all subsequent studies.

\section{Effect of Fermentation Time on $\alpha$-amylase Production}

Incubation period required to reach maximum enzyme level depends on culture characteristics and it is based on growth speed and enzyme production [16]. To determine the best fermentation period, tests were conducted from $24 \mathrm{~h}$ to $144 \mathrm{~h}$. A gradual increase was seen in enzyme production from 24 to $48 \mathrm{~h}$ and maximum enzyme activity was determined to be $2.820 \mathrm{U} / \mathrm{mg}$ in $48 \mathrm{~h}$, after 
94 | M.S. Yalçın and S. Özdemir / Hacettepe J. Biol. \& Chem., 2018, 46 (1), 91-99

Table 1. Morphological, physiological and biochemical tests.

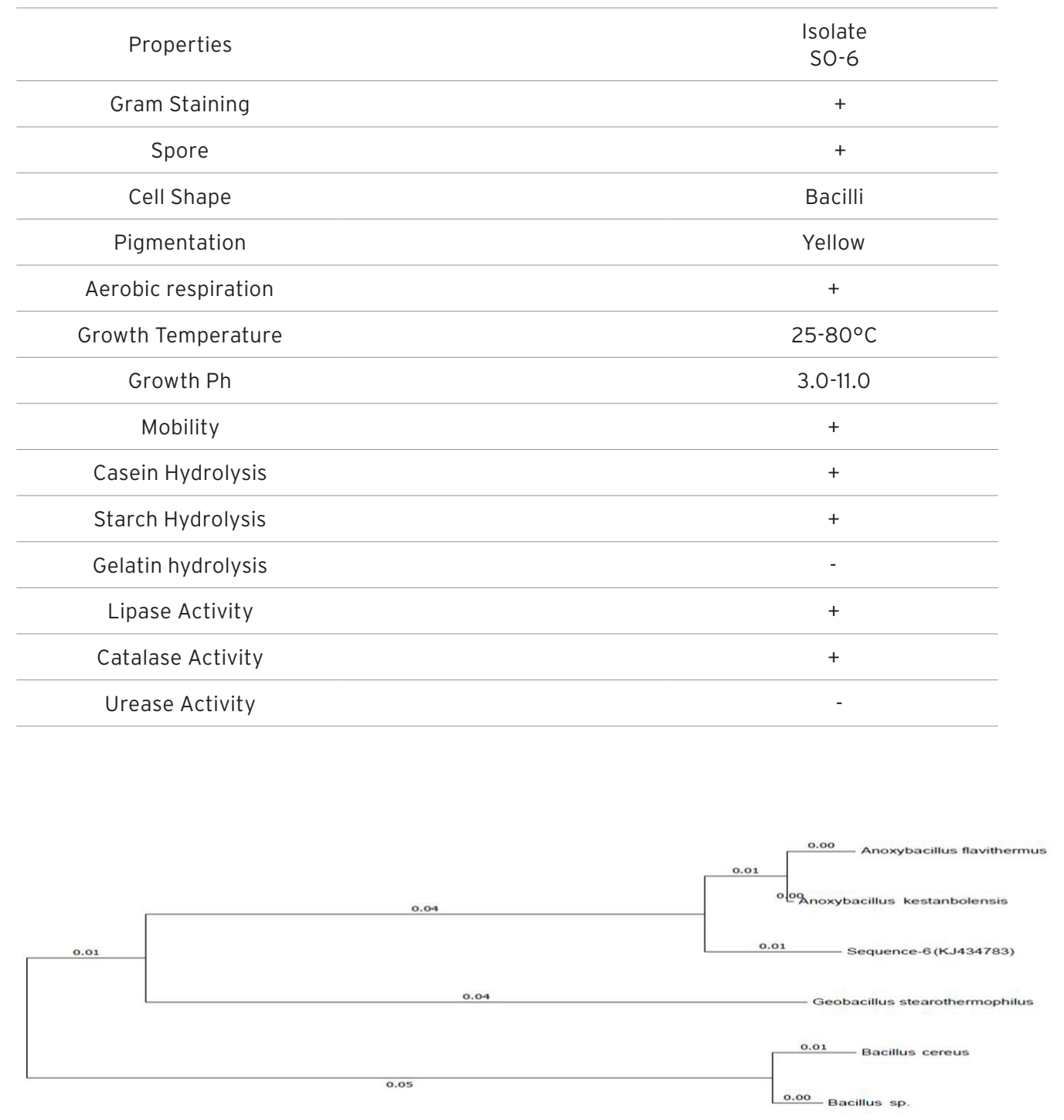

Figure 1. Evolutionary relationships of taxa.

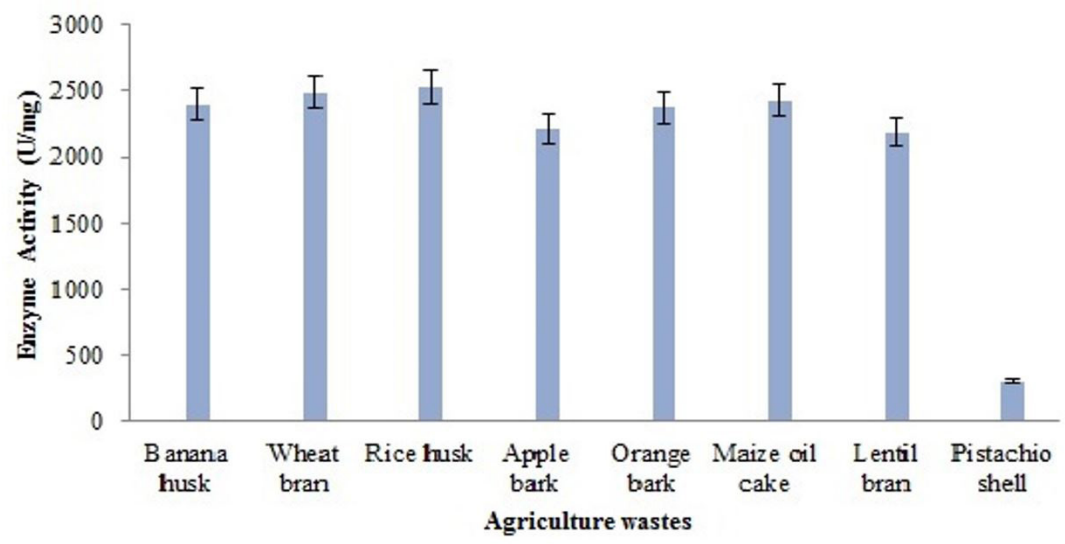

Figure 2. Effect of different substrates on $\alpha$-amylase production by Anoxybacillus sp. using SSF. Process conditions: initial moisture content $50 \%$ (\% by volume per mass), inoculum size 30\% (\% by volume per mass), particle size 1.000 $\mu \mathrm{m}$, fermentation time $24 \mathrm{~h}, \mathrm{pH} 7.0$ and temperature $55^{\circ} \mathrm{C}$. 


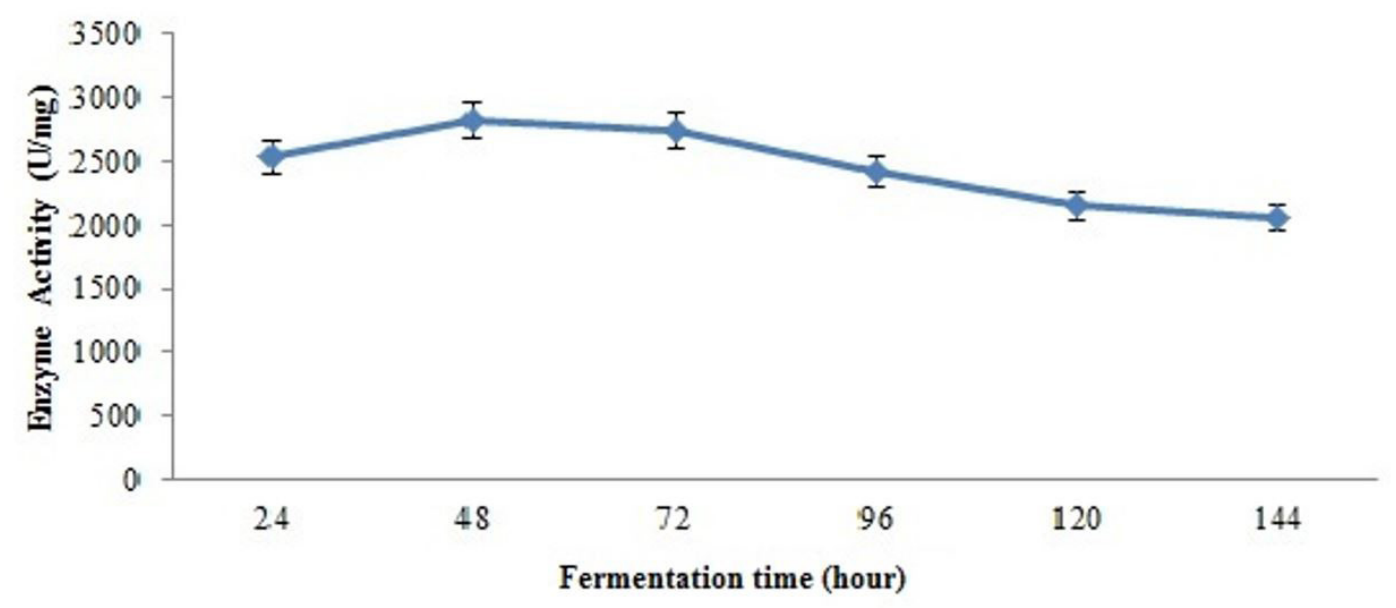

Figure 3. Effect of fermentation time on $\alpha$-amylase production by Anoxybacillus sp. under SSF using RH as substrate. Process conditions: initial moisture content $50 \%$ (\% by volume per mass), inoculum size 30\% (\% by volume per mass), particle size $1.000 \mu \mathrm{m}$, temperature $55^{\circ} \mathrm{C}$ and $\mathrm{pH} 7.0$.

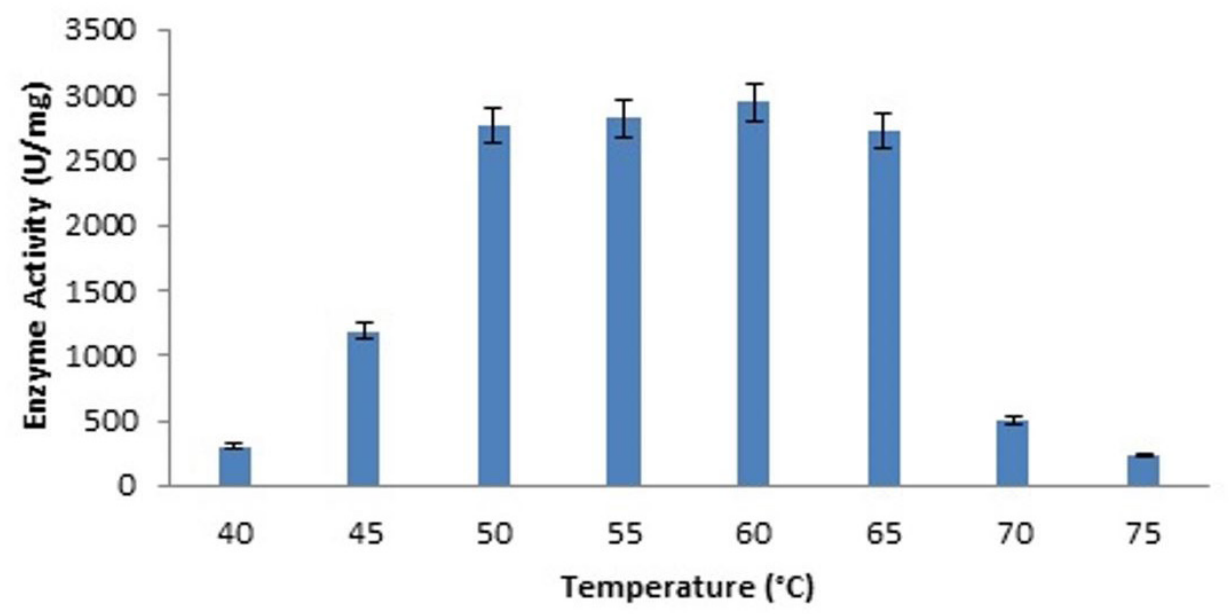

Figure 4. Effect of temperature on $\alpha$-amylase production by Anoxybacillus sp. under SSF using RH as substrate. Process conditions: initial moisture content $50 \%$ (\% by volume per mass), inoculum size $30 \%$ ( $\%$ by volume per mass), particle size $1.000 \mu \mathrm{m}$, fermentation time $48 \mathrm{~h}$ and $\mathrm{pH} 7.0$.

which a gradual decrease was observed (Figure 3). Decrease in enzyme efficiency after that hour may depend on the depletion of media or the denaturation of enzyme resulting from its interaction with other components in the medium or a variation in $\mathrm{pH}$ of the medium [17]. Fermentation time was applied as $48 \mathrm{~h}$ in all subsequent experimental works.

\section{Effect of Temperature on Bacterial Growth and $\alpha$-amylase Production}

Temperature control in substrate bed has crucial importance to SSF because bacterial growth and the production of enzymes or metabolites is generally sensitive to temperature $[15,18,19]$. As shown in Figure 4, the enzyme activity increased 9.7 times with an increasing in the temperature from 40 to $60^{\circ} \mathrm{C}$ and the optimum enzyme production temperature of Anoxybacillus sp. was determined as $60^{\circ} \mathrm{C}(2.942 \mathrm{U} / \mathrm{mg})$. The production of thermophiles at high temperatures is technically and economically important that it minimizes the risk of contamination, facilitates mixture by reducing adhesiveness, and causes a high level of substrate solubility [20]. The enzyme activity decreased 13 times when the temperature increased from 60 to $75^{\circ} \mathrm{C}$. This reduction can be attributed to the decreased of bacterial growth 
above the optimum fermentation temperature (data not shown). Thus, temperature in the substrate bed of $60^{\circ} \mathrm{C}$ was used for further studies.

\section{Effect of $\mathrm{pH}$ on $\alpha$-amylase Production}

$\mathrm{pH}$ is one of the important factors for each fermentation process and depends on the type of moistening agent used in media. Each microorganism has an optimum $\mathrm{pH}$ range so that it can grow and become active. A substrate formation taking account of the buffering capacity of different components used or a buffer formulation containing components which do not have a harmful effect on biological effectiveness should be used for overcoming $\mathrm{pH}$ variation problem during SSF process [21]. As inferred from Figure 5, optimum $\mathrm{pH}$ value was determined to be $6.0(3.060 \mathrm{U} / \mathrm{mg})$ by using different buffers for various $\mathrm{pH}$ values for the production of $\alpha^{-}$ amylase. Subsequent works were carried out by using this value as a basis.

\section{Effect of Substrate Particle Size on $\alpha$-amylase Production}

The size of substrate particle is the most critical factor for microbial growth and enzyme activity [22]. The enzyme activity rised up 8.2 times with an increasing in the particle size from 500 to $1.500 \mu \mathrm{m}$. The highest enzyme production (3.060 $\mathrm{U} / \mathrm{mg}$ ) was found in the medium with a particle size of $1500 \mu \mathrm{m}$ (Figure 6). It is preferred for microbial growth as surface are might grow due to smaller particle size, but growth may be inhibited as substrate may be agglomerated in smaller sizes. At $2.000 \mu \mathrm{m}$, activity of enzyme dropped down up to $57.3 \%$ as compared to the optimum enzyme activity at $1.500 \mu \mathrm{m}$. In larger sizes, it is not preferred as an insufficient surftace area will be formed for microbial attack [23]. Substrate with $1.500 \mu \mathrm{m}$ particle size was preferred for subsequent works.

\section{Effect of Initial Moisture Content of Substrate on $\alpha$-amylase Production}

The critical importance of humidity level in a SSF setting and its effects on the biosynthesis and oscillation of enzymes may be attributed to the effect of humidity on the physical characteristics of solid particles in the medium [16]. A low humidity content will cause a decrease in the solubility of substrate nutrients and a lower inflation level [24]. However, it is believed that an increase in humidity level reduces the porosity of wheat bran and thus, limits oxygen transfer [18]. As shown in Figure 7, maximum enzyme efficiency i.e. 3.175 $\mathrm{U} / \mathrm{mg}$ was obtained in $60 \%$ substrate humidity content in trials conducted for determining the optimum humidity content because of its importance. Subsequent works were carried out based on this humidity content.

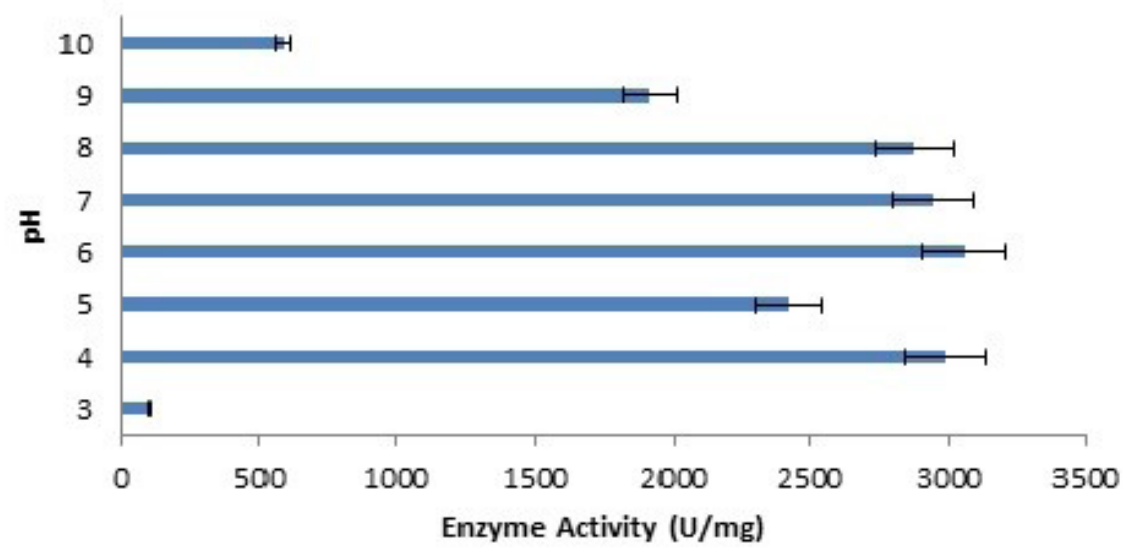

Figure 5. Effect of $\mathrm{pH}$ on $\alpha$-amylase production by Anoxybacillus sp. under SSF using RH as substrate. Process conditions: initial moisture content $50 \%$ (\% by volume per mass), inoculum size $30 \%$ (\% by volume per mass), particle size $1.000 \mu \mathrm{m}$, fermentation time $48 \mathrm{~h}$ and temperature $60^{\circ} \mathrm{C}$. 


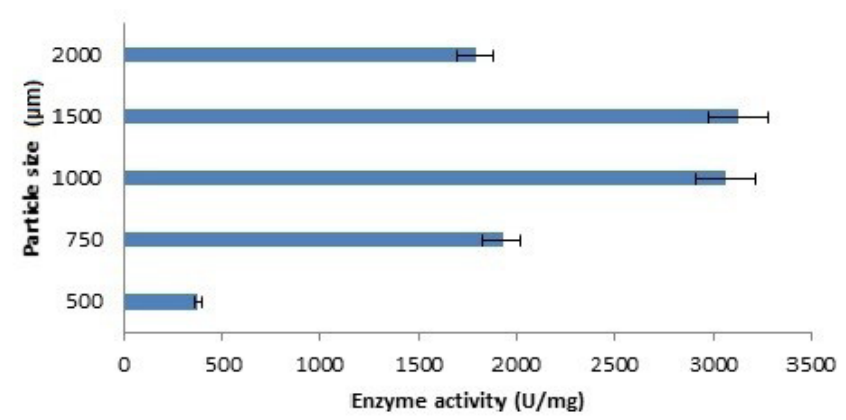

Figure 6. Effect of substrate particle size $(\mu \mathrm{m})$ on $\alpha$-amylase production by Anoxybacillus sp. under SSF using $\mathrm{RH}$ as substrate. Process conditions: initial moisture content $50 \%$ (\% by volume per mass), inoculum size $30 \%$ (\% by volume per mass), fermentation time $48 \mathrm{~h}, \mathrm{pH} 6.0$ and temperature $60^{\circ} \mathrm{C}$.

\section{Effect of inoculum Size on $\alpha$-amylase Production}

Inoculum level is one of the other important parameters for the production of $\alpha$-amylase [25]. As presented in Figure 8, the lowest enzyme yield was obtained at the lowest value of $10 \%$ inoculum size, whereas the maximum enzyme yield $(3.274$ $\mathrm{U} / \mathrm{mg}$ ) was obtained at $40 \%$ inoculum size. At $60 \%$ inoculum size activity of enzyme dropped down up to $55.5 \%$ as compared to the optimum enzyme activity at $40 \%$ inoculum size. This results agreed with that of Ozdemir et al., [25]. Thus, $40 \%$ was used for further studies.

\section{Effect of Metal Ions on $\alpha$-amylase Production}

Different metals exhibit different behavior in terms of their ability to act as an effector [26]. Metallic co-factors are important for enzymatic reaction because the existence or absence of metal regulates enzyme activity. The presence of a specific metallic ion in addition to the source of basic nutrient may inhibit or reinforce enzyme production. $\mathrm{Co}^{2+}, \mathrm{Ca}^{2+}, \mathrm{Mn}^{2+}, \mathrm{Cu}^{2+}, \mathrm{Pb}^{2+}$ and $\mathrm{Cd}^{2+}$ metal ions in a $5 \mathrm{mg} / \mathrm{L}$ concentration and a control group without any metal ion were tested under the optimum fermentation conditions. As shown in Figure $9, \alpha$-amylase production increased in presence of $\mathrm{Ca}^{2+}, \mathrm{Co}^{2+}$ and $\mathrm{Mn}^{2+}$ ions, but slightly decreased in presence of $\mathrm{Cu}^{2+}$. Michelin et al., (2010) reported that amylase was activated by calcium (34\%), cobalt (41\%), and manganese chlorates (47\%). Saboury (2002) also determined $\mathrm{Co}^{2+}$ as activator of $\alpha$-amylase from Bacillus amyloliquefaciens.

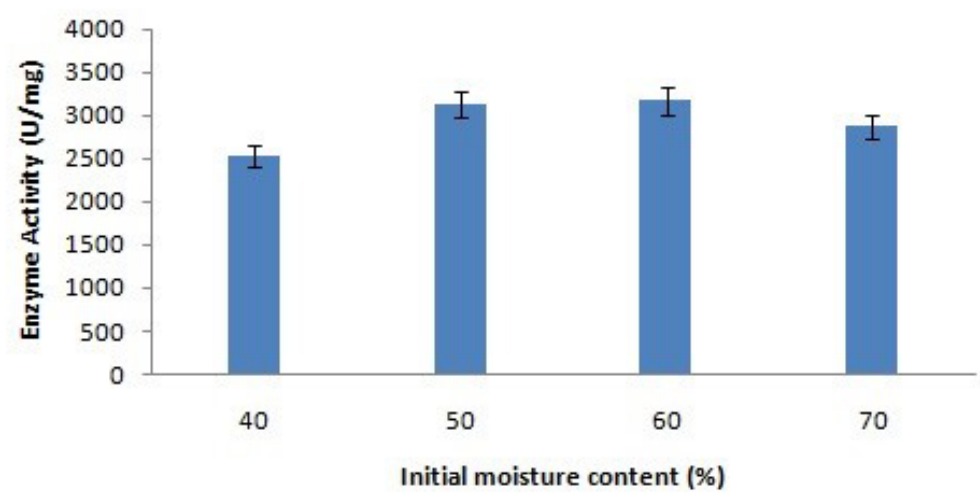

Figure 7. Effect of initial moisture content on $\alpha$-amylase production by Anoxybacillus sp. under SSF using RH as substrate. Process conditions: inoculum size $30 \%$ (\% by volume per mass), particle size $1.500 \mu \mathrm{m}$, fermentation time $48 \mathrm{~h}$, $\mathrm{pH} 6.0$ and temperature $60^{\circ} \mathrm{C}$. 


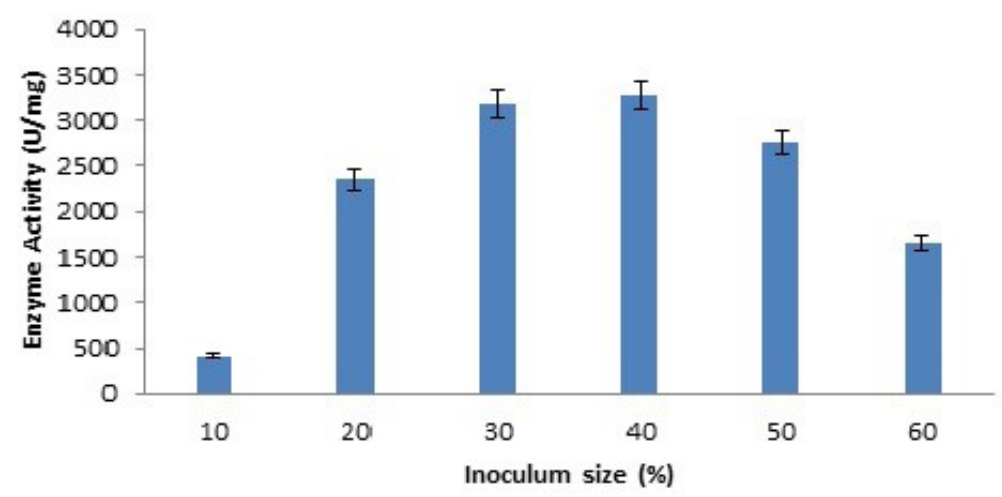

Figure 8. Effect of inoculum size (\% by volume per mass) on $\alpha$-amylase production by Anoxybacillus sp. under SSF using RH as substrate. Process conditions: initial moisture content $60 \%$ (\% by volume per mass), particle size $1.500 \mu \mathrm{m}$, fermentation time $48 \mathrm{~h}, \mathrm{pH} 6.0$ and temperature $60^{\circ} \mathrm{C}$.

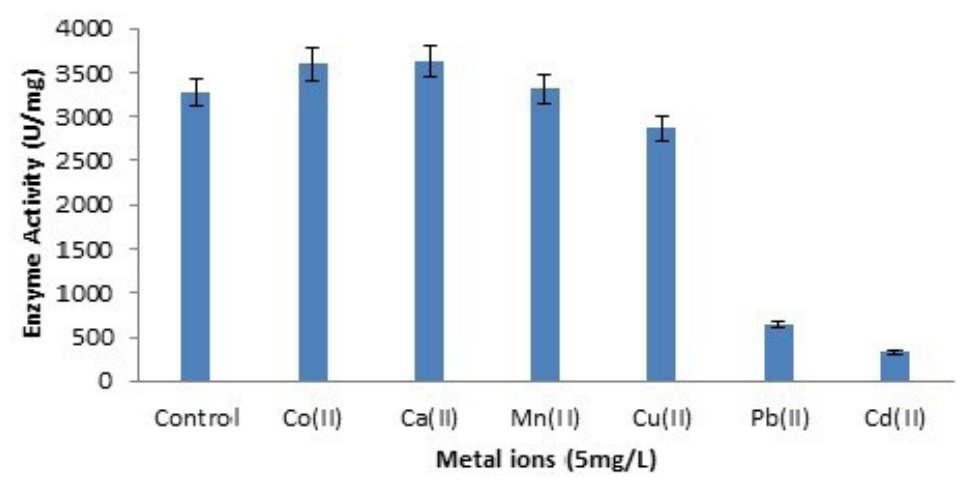

Figure 9. Effect of metal ions on $\alpha$-amylase production by Anoxybacillus sp. under SSF using RH as substrate. Process conditions: initial moisture content $60 \%$ ( $\%$ by volume per mass), inoculum size $40 \%$ ( $\%$ by volume per mass), particle size $1.500 \mu \mathrm{m}$, fermentation time $48 \mathrm{~h}, \mathrm{pH} 6.0$ and temperature $60^{\circ} \mathrm{C}$.

Our results showed good similarity with their findings. Enzyme production sharply decreased in presence of $\mathrm{Pb}^{2+}$ and $\mathrm{Cd}^{2+}$ ions. It is well known that $\mathrm{Pb}^{2+}$ and $\mathrm{Cd}^{2+}$ ions are not essential for living organisms. This reduction can be attributed to the inhibition of bacterial growth because of toxic effect of $\mathrm{Pb}^{2+}$ and $\mathrm{Cd}^{2+}$ ions (data not shown).

\section{CONCLUSIONS}

This study determined optimum conditions for the production of thermostable $\alpha$-amylase through SSF technique by using thermophilic Anoxybacillus sp. The effects on enzyme production of different agricultural wastes, fermentation period, temperature, $\mathrm{pH}$, particle size, humidity, inoculum level, and metal ions were explored and enzyme production was optimized. The highest enzyme activity was obtained as $3.628 \mathrm{U} / \mathrm{mg}$ at 48 th hour, $60^{\circ} \mathrm{C}, \mathrm{pH}: 6.0,1500 \mu \mathrm{m}$ particle size, $60 \%$ initial humidity and $40 \%$ inoculation volume and in presence of $\mathrm{Ca}^{2+}$ ion by using $\mathrm{RH}$ as substrate. 


\section{References}

1. R. Gupta, P. Gigras, H. Mohapatra, V.K. Goswami, B. Chauhan, Microbial $\alpha$-amylases: A biotechnological perspective, Process Biochem., 38 (2003) 1599-1616.

2. R.K. Saxena, K. Dutt, L. Agarwal, P. Nayyar, A highly thermostable and alkaline amylase from a Bacillus sp. PN5, Bioresour. Technol., 98 (2007) 260-265.

3. A. Pandey, C.R. Soccol, P. Nigam, V.T. Soccol, Biotechnological potential of agro-industrial residues: I. Sugarcane bagasse, Bioresour. Technol., 74 (2000) 69-80.

4. B. Arikan, Highly thermostable, thermophilic, alkaline, SDS and chelato rresistant amylase from a thermophilic Bacillus sp. Isolate A3-15, Bioresour. Technol., 99 (2008) 3071-3076.

5. M. Asgher, M.J. Asad, S.U. Rahman, R.L. Legge, A thermostable $\alpha$-amylase from a moderately thermophilic Bacillus subtilis strain for starch processing, J. Food. Eng.,79 (2007) 950-955.

6. C.R. Soccol, E.S. Ferreira da Costa, L.A.J. Letti, S.G. Karp, A.L. Woiciechowski, L.P.S. Vandenberghe, Recent developments and innovations in solid state fermentation, Biotechnology Research\&Innovation. 1 (2017) 52-71.

7. A. Pandey, Solid-state fermentation, Biochem. Eng. J.,13 (2003) 81-84.

8. C.R. Soccol, L.P.S. Vandenberghe, Overview of solid state fermentation in Brazil, Biochem. Eng. J., 13 (2003) 205-218.

9. R.Kuhad, D. Deswal, S. Sharma, A. Bhattacharya, K. Jain, A. Kaur, Revisiting cellulase production and redefining current strategies based on major challenges, Renew. Sust. Energ. Rev., 55 (2016) 249272.

10. D. Pessoa, A. Finkler, A. Machado, L. Luz, D. Mitchell, Fluid dynamics simulation of a pilot-scale solid-state fermentation bioreactor, Chem. Eng. Trans., 49 (2016) 49-54.

11. D.H. Bergey, Thermophilic bacteria, J. Bacteriol., 4 (1919) 301-306.

12. T. Aanniz, M. Ouadghiri, M. Melloul, J. Swings, E. Elfahime, J. Ibijbijen, M. Ismaili, M. Amar, Thermophilic bacteria in Moroccan hot springs, salt marshes and desert soils, Braz. J. Microbiol., 46 (2015) 443-453.

13. K. Tamura, J. Dudley, M. Nei, S. Kumar, MEGA4: molecular evolutionary genetics analysis (MEGA), Mol. Biol. Evol., 24 (2007) 1596-1599.

14. P. Bernfeld, Amylases, $\alpha$ and $\beta$. In: Methods in Enzymology I. Academic, New York (1955).

15. K.S. Harmeet, S. Kanupriya, K.G. Jugal, K.S. Sanjeev, Production of a thermostable $\alpha$-amylase from Bacillus sp. PS-7 by solid state fermentation and its synergistic use in the hydrolysis of malt starch for alcohol production, Process Biochem., 40 (2005) 525-534.
16. A. Kunamneni, K. Permaul, S. Singh, Amylase production in solid-state fermentation by the thermophilic fungus Thermomyces lanuginosus, J. Biosci. Bioeng., 100 (2005) 168-171.

17. N. Mahanta, A. Gupta, SK. Khare, Production of protease and lipase by solvent tolerant Pseudomonas aeruginosa PseA in solid-state fermentation using Jatropha curcas seed cake as substrate, Bioresour. Technol., 99 (2008) 1729-1735.

18. K.R. Babu, T. Satyanarayana, $\alpha$-Amylase production by thermophilic Bacillus coagulans in solid state fermentation, Process, Biochem., 30 (1995) 305-309.

19. S.M. Kotwal, M.M. Gote, S.R. Sainkar, M.I. Khan, J.M Khire, Production of $\alpha$-galactosidase by thermophilic fungus Humicola sp. in solid state fermentation and its application in soya milk hydrolysis, Process Biochem., 33 (1998) 337-43.

20. P. Turner, G. Mamoand E.N. Karlsson, Potential and utilization of thermophiles and thermostable enzymes in biorefining, Microbial. Cell Factories., 6:9 (2007) 1-23.

21. A. Pandey, C.R. Soccol, J.A. Rodriguez Leon, P. Nigam, Factors that influence on solid state fermentation. In: Pandey A, ed. Solid State Fermentation in Biotechnology: Fundamentals and Applications. New Delhi: Asiatech Publishers Inc., (2001) pp. 21-9.

22. B.L. Luiand, Y.M. Tzeng, Water content and water activity for the production of cyclodepsipeptide in solid state fermentation, Biotechnol. Lett., 21 (1999) 657-661.

23. M. Elibol, A.R. Moreira, Optimization some factors affecting alkaline protease production by a marine bacterium Teredinobacter turnirae under solidstate substrate fermentation, Process. Biochem., 40 (2005) 1951-1956.

24. R.V. Feniksova, A.S. Tikhomirova, E.E. Rakhleeva, Conditions for forming amylase and proteinase in surface cultures of Bacillus subtilis, Microbiologia., 29 (1960) 745-748.

25. S. Özdemir, F. Matpan, V. Okumus, A. Dündar, M.S Ulutas, M. Kumru, Isolation of a thermophilic Anoxybacillus flavithermus sp. nov. and production of thermostable $\alpha$-amylase under solid-state fermentation (SSF), Ann. Microbiol., 62 (2012) 13671375.

26. W.F. Li, X.X. Zhou, P. Lu, Structural features of thermozymes, Biotechnol. Adv., 23 (2008) 271-281.

27. M. Michelin, T. M. Silva, V. M. Benassi, S. C. PeixotoNogueira, L. A. Moraes, J. M. Leão, J. A. Jorge, H. F. Terenzi, M.L.Polizeli, Purification and characterization of a thermostable a-amylase produced by the fungus Paecilomyces variotii, Carbohydrate Res. 345 (2010) 2348-2353.

28. A.A. Saboury, Stability, activity and binding properties study of $\alpha$-amylase upon interaction with $\mathrm{Ca}^{2+}$ and $\mathrm{Co}^{2+}$, Biologia, 57 (2002) 221-228. 